https://doi.org/10.37208/tgn27213

\section{Dr Oliver Rackham, the ancient Mugdock Wood and the boundary pollard oak that never was}

\author{
J.H. Dickson \\ 15 Craigton Road, Milngavie G62 7JH \\ E-mail: prof.j.h.dickson@ gmail.com
}

Sadly on 12th February 2015 the noted botanist Oliver Rackham died suddenly and unexpectedly. I was privileged to have met him in the early 1960 s when he and I were young researchers at the University of Cambridge, England. I had great admiration for his depth and breadth of knowledge which included an ability to read mediaeval Latin. Oliver could leave me overawed at times.

Oliver was the best known British exponent of the historical ecology of woodlands and became famous with the publication of his first two books in consecutive years: Hayley Wood and Trees and Woodlands in the British Landscape (Rackham, 1975, 1976). Although the latter especially is a great read and full of interest, there is something annoyingly wrong about the title. It should have referred to "the English Landscape" because there is so little in the first edition of the book about the other parts of the U.K. His book The Ash Tree (Rackham, 2014) is every bit as cogent, informative and readable as the first books and all the various others in between. Finally in 2019 there appeared a posthumous book on the woodlands of a part of Cornwall The Ancient Woods of the Helford River (Rackham, 2019).

In 1985 Oliver came to Scotland and stayed for a few days with my family in Milngavie, East Dunbartonshire. I showed him the oak woodlands (Quercus petraea and Q. robur) at Mugdock (East Dunbartonshire and Stirling), Garscadden (Glasgow) and Inchcailloch (Loch Lomond) and was glad to get his observations on all three places.

Oliver kept very many small identical notebooks of his woodland studies and other botanical topics. Painstakingly pencil-written in a clear hand, they are kept in the library of Corpus Christi College, University of Cambridge. There Oliver was an undergraduate, then a Fellow and eventually the Master (for a three year stint, the usual practice in that college). Very conveniently, the notebooks are now digitised and online and can be accessed at http://cudl.lib.cam.ac.uk/collections/rackham/1.

Oliver published about Mugdock Wood in his 2006 book and made the curious statement that few of the oaks had been coppiced. Certainly by comparison with the vast majority of the many alders (Alnus glutinosa) that have been coppiced, the oaks are much less so. However, on the southwest-facing steep slope just above the main track there are scores of coppiced oaks (Fig. 1).

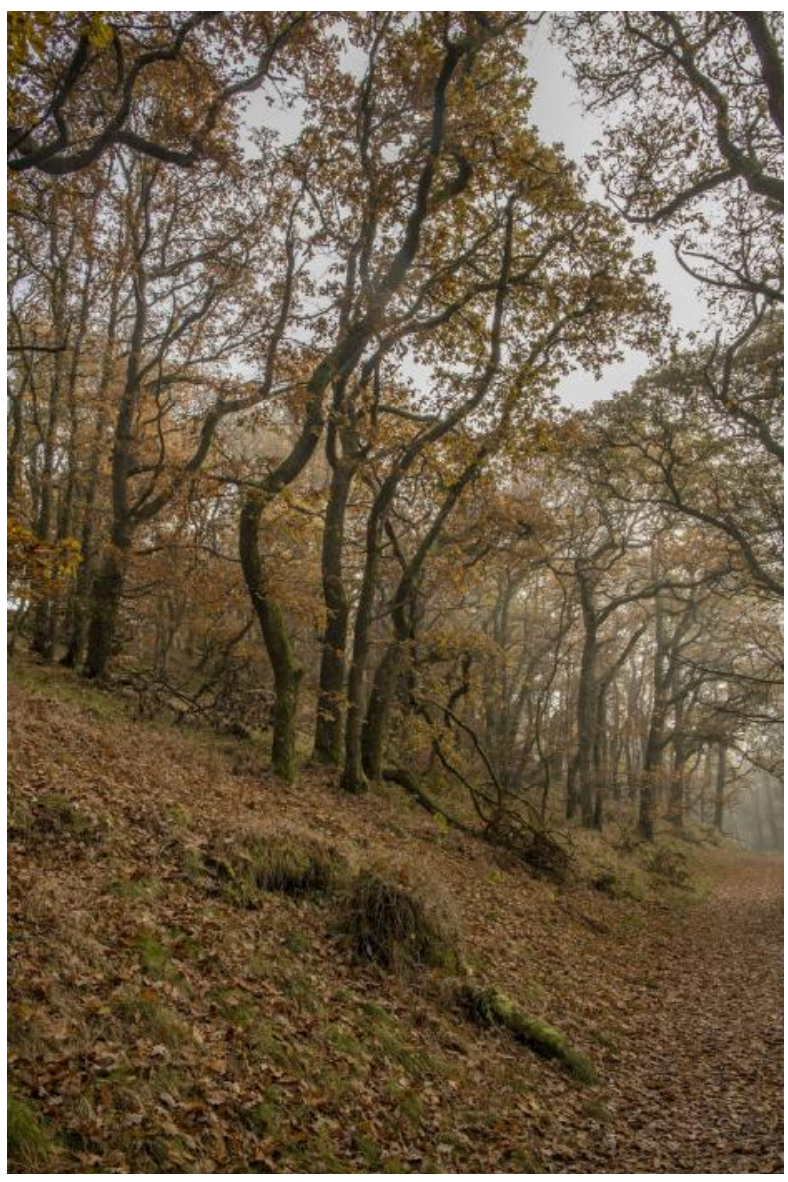

Fig. 1. View of Mugdock Wood, East Dunbartonshire, Scotland, from the main track (now part of the West Highland Way) looking southeast and showing some of the many multitrunked oaks. (Photo: D.C. Palmar)

At the northwest end of the wood, close to the road known as the Khyber Pass, Oliver was impressed by a coppiced oak with a ring of several trunks so widespread that coppicing must have occurred repeatedly for perhaps 400 to 500 years according to him (Fig. 2). I was all ears. Trees are shown near Mugdock Castle in the Dunbartonshire map of the Blaeu Atlas of Scotland published in 1654. Indisputably it is an ancient wood. Documents first mention it in the 13th century. According to Oliver, Mugdock is a Welsh name (Maesiddwg). Therefore one has to suppose that it goes back to the Britons of Strathclyde who spoke an early form of Welsh.

In the wood on a steep slope very close to the Allander Water we came across an oak which Oliver declared could be a boundary pollard. I was even more all ears. It was the first such tree to be recognised in Scotland for all I knew. However, revealingly, there is no mention of that tree in Oliver's notes or in his 2006 book. So evidently he had doubts even before the first writing up. 


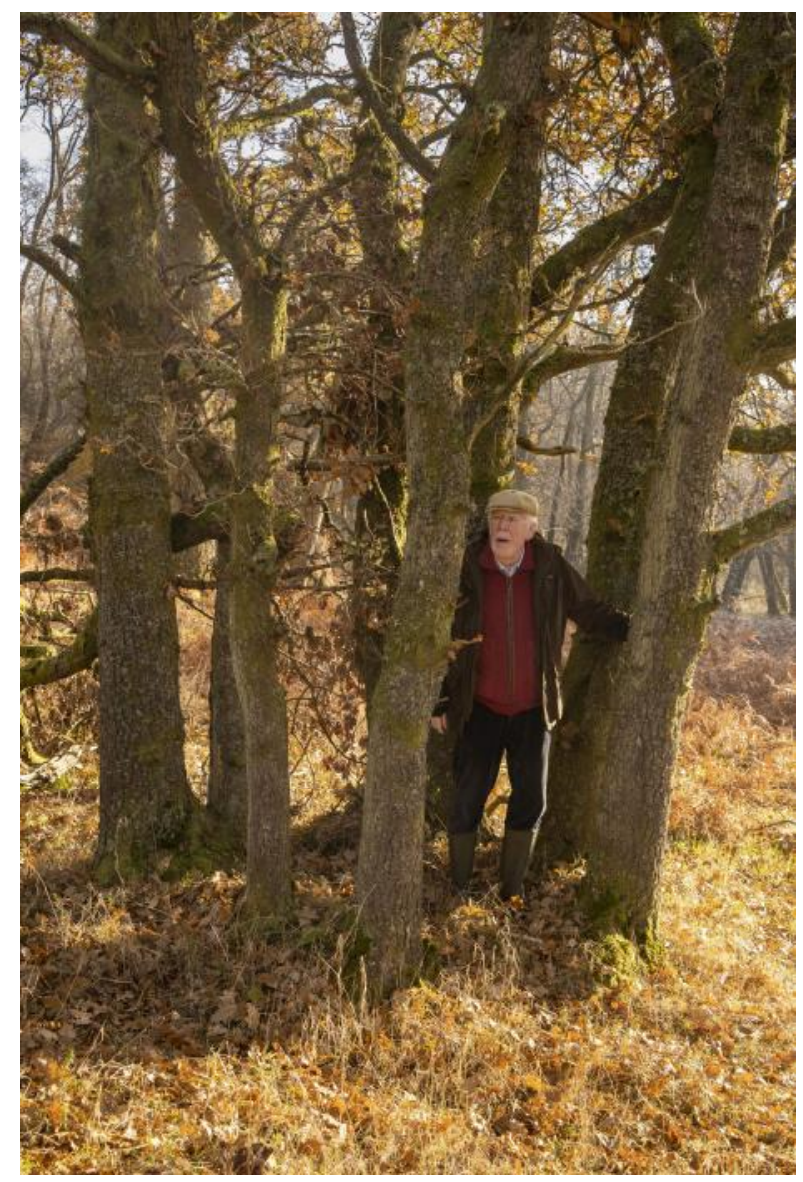

Fig. 2. The author at the anciently and repeatedly coppiced oak (Quercus petraea and Q. robur) at the western end of Mugdock Wood, East Dunbartonshire, Scotland. (Photo: D.C. Palmar)

However, the story does not end there. In the late 1980s under my supervision Mrs Jean Stevenson was a botany undergraduate and carried out a final year project on Mugdock Wood (Stevenson, 1990). I had shown Mrs Stevenson the boundary pollard of which she makes no mention in her paper. The reason was that she found that it was not a pollard, boundary or otherwise, but very surprisingly a coppiced oak. How can one mistake a pollard for a coppiced tree? The answer is: very steep topography, which had changed markedly with enough of the ground disappearing downslope leaving what looked like a trunk being in reality a massive, exposed root. Furthermore, a simple inspection at what had been the former soil level showed colour changes and even some tiny pebbles in the bark. I told Oliver about it but he did not reply, if I recall correctly.

Not having visited the tree in question for many years, I tried to find it twice in 2017 without success. It may well have disappeared long since downslope and into the Allander Water.

I am grateful to David Palmar for taking the photographs used in this article.

\section{REFERENCES}

Rackham, O. (1975). Hayley Wood: Its History and Ecology. Cambridgeshire \& Isle of Ely Naturalists' Trust.

Rackham, O. (1976). Trees and Woodland in the British Landscape. (1st edn.). J.M. Dent \& Sons, London.

Rackham, O. (2006). Woodlands. HarperCollins, Glasgow.

Rackham, O. (2014). The Ash Tree. Little Toller Books, Dorchester.

Rackham, O. (2019). The Ancient Woods of the Helford River. Little Toller Books, Dorchester.

Stevenson, J.F. (1990). How ancient is the woodland of Mugdock? Scottish Forestry 44, 161-172. 